\title{
STUDIES ON THE PATHOGENESIS OF THE ETHANOL-INDUCED FATTY LIVER. I. SYNTHESIS AND OXIDATION OF FATTY ACIDS BY THE LIVER*
}

\author{
By GILBERTO REBOUÇAS † AND KURT J. ISSELBACHER \\ (From the Department of Medicine, Harvard Medical School and the Gastroenterology Unit \\ of the Medical Services, Massachusetts General Hospital, Boston, Mass.)
}

(Submitted for publication November 28, 1960; accepted March 17, 1961.

In studying the effects of ethanol on the liver, we have directed our attention to the manner by which ethanol intoxication in animals causes an acute fatty liver $(1,2)$. Although the mechanism involved is still not well understood, the production of the fatty liver under these conditions probably involves one or more of the following four processes: 1) increased hepatic lipid synthesis, 2) decreased hepatic lipid utilization (e.g., oxidation), 3 ) increased transport of fatty acids from peripheral fat depots or 4) decreased release of lipid from the liver. Mallov and Bloch (1) originally suggested that the fatty liver following ethanol administration was due to an increased transport of fat from the depots to the liver, but later (3) considered that the increased hepatic lipid might be the result of increased hepatic fatty acid synthesis. Consistent with the latter concept are the observations of Lieber, DeCarli and Schmid (4, 5) that ethanol, in vivo and in vitro, stimulates fatty acid synthesis in the liver. These authors attributed the enhanced fatty acid synthesis to an increased production of reduced diphosphopyridine nucleotide (DPNH) produced by the oxidation of ethanol (5). On the other hand, good evidence has been presented recently $(6,7)$ that increased transport of fatty acids to the liver from the fat depots may be the major mechanism for the fatty liver produced by ethanol as well as by other agents, such as ethionine and carbon tetrachloride.

To gain further insight into the mechanism whereby ethanol intoxication produces a fatty liver, we have investigated the four processes referred to above in order to determine the extent to which one or more of them may be involved.

\footnotetext{
* This work has been supported in part by Grant A-1392 from the National Institutes of Health, Bethesda, Md.

$\dagger$ Fellow of the W. K. Kellogg Foundation and the American College of Physicians. Present address : Hosvital das Clinicas, Salvador, Bahia, Brazil.
}

The present report is a study of changes in hepatic fatty acid synthesis and oxidation following ethanol administration in vivo and in vitro. Observations on the role of reduced and oxidized diphosphopyridine nucleotides are also presented. A subsequent report will deal with studies on lipid transport.

\section{MATERIALS AND METHODS}

Palmitate-1-C $\mathrm{C}^{14}$ (specific activity $5 \times 10^{6} \mathrm{cpm}$ per $\mu$ mole) was obtained from Volk Radiochemical Co., Chicago, IIl., and purified as described previously (8). Acetate$1-C^{14}$ was purchased from New England Nuclear Corporation, Boston, Mass. Diphosphopyridine nucleotide (DPN) was obtained from Sigma Chemical Co., St. Louis, Mo. Hyamine-10X was prepared according to the method of Passman, as modified by Eisenberg (9). Female albino rats (Charles River Laboratories, Boston, Mass.), weighing between 180 and $250 \mathrm{~g}$ and maintained on Purina Chow were used throughout this investigation.

Acetate-1-C is incorporation into liver lipid. The animals were given, by stomach tube, $9.3 \mathrm{~g}$ per $\mathrm{kg}$ ethanol (50 per cent by volume), isocaloric amounts of glucose or sorbitol, or equivalent volumes of saline and then fasted for 16 hours. At the end of this period $1 \mathrm{ml}$ of saline containing $20 \mu \mathrm{c}$ acetate-1-C $\mathrm{C}^{14}$ (specific activity 25 to $27 \mu \mathrm{c}$ per $\mathrm{mg}$ ) was injected into the portal vein with the animals under light ether anesthesia. The rats were sacrificed 45 minutes later. When the animals were pretreated with nicotinamide, they received $500 \mathrm{mg}$ per $\mathrm{kg}$ i.p. daily for 3 days prior to ethanol administration. Control animals were injected with saline. Studies on hypophysectomized rats (Charles River Laboratories) were not carried out until 2 weeks after the operation. In the experiments on cordotomized animals, the operation was performed at the C-4 to C-6 level 1 to 4 hours prior to ethanol or saline treatment. Both hypophysectomized and cordotomized rats, because of a greater sensitivity to ethanol intoxication, received a smaller dose of ethanol ( $6.2 \mathrm{~g}$ per $\mathrm{kg}$ ).

At the end of the in vivo part of the experiment, the animals were killed by cervical dislocation and the livers quickly excised. Lipid was extracted with chloroformmethanol according to Folch, Lees and Sloane Stanley (10). The chloroform fraction was evaporated to dryness and taken up in $10 \mathrm{ml}$ petroleum ether. Aliquots were assayed for radioactivity in a Packard Tri-Carb 
TABLE I

Some factors influencing lipid accumulation and $C^{14}$-acetate incorporation into lipids in rat liver

\begin{tabular}{|c|c|c|c|}
\hline $\begin{array}{l}\text { No. of } \\
\text { animals }\end{array}$ & Treatment* & $\begin{array}{l}\text { Total liver } \\
\text { fatty acids }\end{array}$ & $\begin{array}{l}\text { C14-acetate incorporated } \\
\text { into total liver lipid }\end{array}$ \\
\hline 6 & Saline & $\begin{array}{c}m g / g \\
36.57 \pm 2.13\end{array}$ & $\begin{array}{l}\% \text { injected cpm/g liver } \\
0.058 \pm 0.016\end{array}$ \\
\hline 6 & Glucose & $\begin{array}{l}32.42 \pm 1.99 \\
(\mathrm{p} 0.001) \ddagger\end{array}$ & $\begin{array}{l}0.250 \pm 0.113 \\
(\mathrm{p} 0.001)\end{array}$ \\
\hline 6 & Ethanol & $\begin{array}{l}71.58 \pm 13.20 \\
(p<0.001)\end{array}$ & $\begin{array}{l}0.379 \pm 0.264 \\
(0.001<p<0.005)\end{array}$ \\
\hline 7 & Sorbitol & $\begin{array}{l}38.77 \pm 6.25 \\
(p>0.1)\end{array}$ & $\begin{array}{l}0.233 \pm 0.128 \\
(\mathrm{p} 0.001)\end{array}$ \\
\hline
\end{tabular}

* Rats were intubated with ethanol $(9.3 \mathrm{~g} / \mathrm{kg})$, isocaloric amounts of glucose or sorbitol, or equivalent volumes of saline and then fasted for 16 hours. Twenty $\mu \mathrm{c} \mathrm{C}^{14}$-acetate was injected into the portal vein and the animals sacrificed 45 minutes later.

$t$ Mean \pm SD.

$\ddagger \mathrm{p}$ Values compared with saline group as control.

liquid scintillation spectrometer, as described previously (8), and analyzed for total fatty acids by the method of Albrink (11).

\section{Palmitate-1-C $\mathrm{C}^{14}$ oxidation to $\mathrm{C}^{14} \mathrm{O}_{2}$}

I. Liver homogenate studies. Rats were either fasted for 16 hours prior to the experiments or given ethanol, glucose or saline (in the doses mentioned above) and then sacrificed in 16 hours. When the animals were pretreated with nicotinamide, they received $500 \mathrm{mg}$ per $\mathrm{kg}$ i.p. daily for 3 days. At the conclusion of the in vivo portion of the experiment, the animals were sacrificed, the livers excised and 1:1 (weight: volume) homogenates prepared in $0.15 \mathrm{M}$ potassium chloride containing $0.05 \mathrm{M}$ nicotinamide. The homogenization was performed at 0 to $4^{\circ} \mathrm{C}$ using a Dounce homogenizer. The standard incubation system consisted of $50 \mathrm{~m} \mu$ moles palmitate-1- $\mathrm{C}^{\mathbf{1 4}}, 80 \mu$ moles potassium phosphate buffer at $\mathrm{pH}$ 7.4 , and approximately $15 \mathrm{mg}$ liver protein in a final volume of $1.5 \mathrm{ml}$. The incubations were carried out in 25-ml Erlenmeyer flasks provided with a center well. The flasks were gassed with 95 per cent oxygen-5 per cent $\mathrm{CO}_{2}$, then sealed with rubber serum caps and agitated for 30 minutes at $37^{\circ} \mathrm{C}$ in a Dubnoff shaking incubator. The reaction was stopped by the injection of $0.25 \mathrm{ml} 10$ $\mathrm{N}$ sulfuric acid into the outer well as described previously (12). One $\mathrm{ml}$ Hyamine was then injected into the center well and the flasks agitated for an additional 30 minutes to trap the $\mathrm{C}^{14} \mathrm{O}_{2}$. Aliquots of the Hyamine- $\mathrm{C}^{14} \mathrm{O}_{2}$ were assayed for radioactivity in the liquid scintillation spectrometer (12).

II. In vivo studies. Rats were given ethanol, glucose or saline and after 4 or 16 hours were injected with 250 $\mathrm{m} \mu$ moles palmitate-1- $\mathrm{C}^{\mathbf{1 4}}$ i.p. They were then placed in special respiratory cages and the expired $\mathrm{CO}_{2}$ trapped in Hyamine as described by Fredrickson and Ono (13). $\mathrm{C}^{14} \mathrm{O}_{2}$ was counted as described above and the $\mathrm{C}^{12} \mathrm{O}_{2}$ determined by titration with $0.1 \mathrm{~N}$ hydrochloric acid.

$D P N$ and $D P N H$ levels in rat liver. The rats were killed by cervical dislocation and the livers irrigated

TABLE II

$D P N$ and $D P N H$ levels in rat liver

\begin{tabular}{|c|c|c|c|c|c|}
\hline Treatment & $\begin{array}{c}\text { No. of } \\
\text { animals }\end{array}$ & DPN & DPNH & $\mathrm{DPN}+\mathrm{DPNH}$ & $\begin{array}{c}\text { Ratio } \\
\text { DPN/DPNH }\end{array}$ \\
\hline & & \multicolumn{4}{|c|}{ mumoles/g liver protein* } \\
\hline $\begin{array}{l}\text { Salinef } \\
\text { Ethanolft } \\
\text { Sorbitolf } \\
\text { Nicotinamide§ } \\
\text { Nicotinamide§ } \\
\text { plus ethanolf }\end{array}$ & $\begin{array}{r}14 \\
8 \\
7 \\
7 \\
7\end{array}$ & $\begin{array}{l}2,237 \pm 271 \\
2,070 \pm 553 \\
2,269 \pm 606 \\
3,669 \pm 848 \\
4,231 \pm 1,884\end{array}$ & $\begin{array}{l}384 \pm 122 \\
696 \pm 251 \\
561 \pm 213 \\
645 \pm 309 \\
916 \pm 397\end{array}$ & $\begin{array}{l}2,636 \pm 316 \\
2,767 \pm 793 \\
2,831 \pm 228 \\
4,314 \pm 928 \\
5,147 \pm 2,074\end{array}$ & $\begin{array}{l}6.32 \pm 1.90 \\
3.12 \pm 0.25 \\
4.37 \pm 1.52 \\
5.65 \pm 0.82 \\
5.01 \pm 2.33\end{array}$ \\
\hline $\begin{array}{l}\text { Cordotomy } \\
\text { Cordotomy } \\
\text { plus ethanol\| }\end{array}$ & $\begin{array}{l}4 \\
4\end{array}$ & $\begin{array}{l}2,256 \pm 310 \\
1,965 \pm 201\end{array}$ & $\begin{array}{l}526 \pm 32 \\
760 \pm 178\end{array}$ & $\begin{array}{l}2,782 \pm 334 \\
2,725 \pm 106\end{array}$ & $\begin{array}{l}4.52 \pm 0.63 \\
2.66 \pm 0.45\end{array}$ \\
\hline
\end{tabular}

* Mean $\pm S D$.

+ Data from Reference 16.

$\ddagger$ Ethanol, $9.3 \mathrm{~g} / \mathrm{kg}$, by stomach tube 16 hours previously; sorbitol in isocaloric amounts (16.3 g/ $\mathrm{kg})$. Nicotinamide, $500 \mathrm{mg} / \mathrm{kg}$ i.p. daily for 3 days.

II Ethanol, $6.2 \mathrm{~g} / \mathrm{kg}$, by stomach tube 1 to 2 hours after cordotomy and 16 hours before sacrifice. 
with $3.0 \mathrm{ml}$ of $0.15 \mathrm{M}$ potassium chloride containing 0.05 $\mathrm{M}$ nicotinamide. The livers were blotted and weighed and then homogenized with $15 \mathrm{ml}$ of cold $0.25 \mathrm{M}$ sucrose $-0.05 \mathrm{M}$ nicotinamide in a chilled metal Waring blender. One-ml aliquots were removed and homogenized with $2.0 \mathrm{ml}$ of 10 per cent trichloroacetic acid for DPN measurements. For DPNH determinations, 2-ml aliquots of the homogenate were added to $3 \mathrm{ml}$ of boiling sodium carbonate $(0.167 \mathrm{M})$. After boiling for 3 to 5 minutes the mixtures were rehomogenized for 30 seconds and placed on ice. DPN and DPNH were then measured fluorometrically by the methyl ethyl ketone method of Ciotti and Kaplan (14). Protein was measured by the biuret reaction (15).

\section{RESULTS}

Incorporation of acetate-1-C ${ }^{14}$ into hepatic lipid

Sixteen hours after the administration of 9.3 $\mathrm{g}$ per $\mathrm{kg}$ of ethanol to female rats, there was a twofold increase in the total fatty acid content of the liver which occurred together with an increased incorporation of labeled acetate into liver lipid (Table I). It was found that ethanol and other agents, such as sorbitol, also produce a significant increase in the hepatic levels of DPNH (Table II). This increase in DPNH is a reflection of the oxidative metabolism of these substances in the liver by the DPN-linked dehydrogenases, alcohol dehydrogenase and sorbitol dehydrogenase. It was of interest that sorbitol, like ethanol, stimulated the incorporation of $\mathrm{C}^{14}$ acetate into hepatic lipid (Table I). However, in contrast to ethanol, treatment of rats with sorbitol did not produce an increase in liver fat. When rats were given glucose in amounts isocaloric to ethanol, there was also a significant stimulation of the incorporation of labeled acetate into lipid, but the liver lipid content was actually decreased under these conditions (Table I).

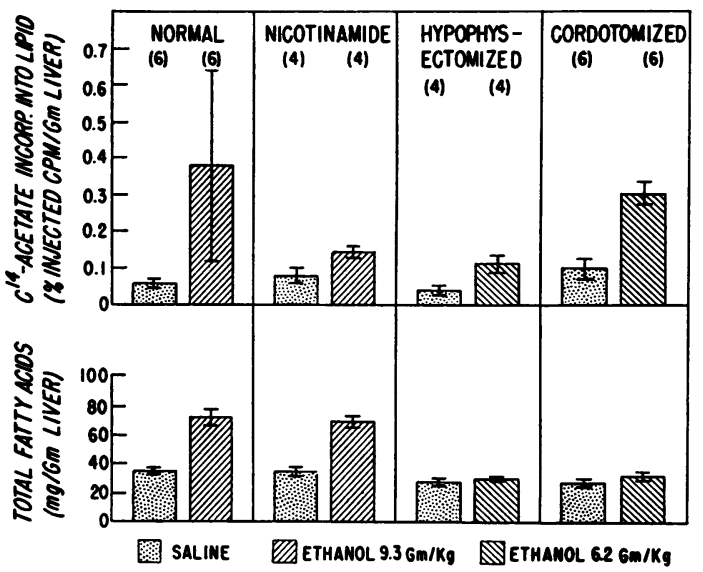

Fig. 1. C C $^{14}$-ACETATE INCORPORATION INTO LIPID AND THE AMOUNT OF HEPATIC LIPID FOLLOWING VARIOUS EXPERIMENTAL PROCEDURes. For details see text. Numbers in parentheses refer to the number of animals.

Further evidence for the dissociation between acetate-1- $\mathrm{C}^{14}$ incorporation into lipid and the development or presence of a fatty liver is provided in Figure 1. Rats were given nicotinamide (500 $\mathrm{mg}$ per $\mathrm{kg}$ ) for 3 days prior to ethanol treatment in order to increase their hepatic levels of DPN and DPNH (Table I) (17). It is evident that nicotinamide pretreatment greatly reduced the stimulatory effect of ethanol on $\mathrm{C}^{14}$-acetate incorporation into lipid but did not reduce the extent of the fatty liver. Studies were also carried out in hypophysectomized and cordotomized animals. These experiments were based on the observations of Mallov and Bloch (1) that hypophysectomy prevents the development of a fatty liver following acute ethanol intoxication in rats, and of Calvert and Brody (7) that cordotomy abolishes the toxic effects of carbon tetrachloride on the liver. It will be seen in Figure 1 that in

TABLE III

Effect of in vitro addition of ethanol, sorbitol or xylitol on $C^{14}$-palmitate oxidation in rat liver homogenates*

\begin{tabular}{|c|c|c|c|c|c|}
\hline \multirow[b]{2}{*}{$\begin{array}{l}\text { No. of } \\
\text { animals }\end{array}$} & \multirow[b]{2}{*}{ Addition } & \multirow[b]{2}{*}{ Final conc. } & \multicolumn{2}{|c|}{$\begin{array}{c}\text { C14-palmitate recovered } \\
\text { as } \mathrm{C}^{14} \mathrm{O}_{2} \dagger\end{array}$} & \multirow[b]{2}{*}{ Change } \\
\hline & & & $\begin{array}{l}\text { Without } \\
\text { addition }\end{array}$ & $\begin{array}{c}\text { With } \\
\text { addition }\end{array}$ & \\
\hline & & moles & \multicolumn{2}{|c|}{ mumoles $/ 100$ mg protein } & $\%$ \\
\hline $\begin{array}{l}8 \\
2 \\
2\end{array}$ & $\begin{array}{l}\text { Ethanol } \\
\text { Sorbitol } \\
\text { Xylitol }\end{array}$ & $\begin{array}{l}0.570 \\
0.013 \\
0.013\end{array}$ & $\begin{array}{l}21 \\
23 \\
24\end{array}$ & $\begin{array}{l}11 \\
17 \\
19\end{array}$ & $\begin{array}{l}-48 \\
-26 \\
-21\end{array}$ \\
\hline
\end{tabular}

* All animals were fasted for 16 hours before sacrifice. Each incubation flask contained: $50 \mathrm{~m} \mu$ moles $\mathrm{C}^{14}$-palmitate, $1 \mathrm{ml}$ liver homogenate containing approximately $15 \mathrm{mg}$ protein, plus the addition. Total volume $1.5 \mathrm{ml}$.

$\dagger$ Figures represent the mean values of all experiments. 
TABLE IV

Effect of in vivo ethanol administration on $C^{14}$-palmitate oxidation in rat liver homogenates and the influence of nicotinamide pretreatment

\begin{tabular}{|c|c|c|c|c|c|}
\hline Group & $\begin{array}{l}\text { No. of } \\
\text { animals }\end{array}$ & $\begin{array}{c}\text { Substance } \\
\text { administered* }\end{array}$ & $\begin{array}{l}\text { Nicotinamide } \\
\text { pretreatment } \dagger\end{array}$ & $\begin{array}{l}\mathrm{C}^{14} \text {-palmitate } \\
\text { recovered as } \\
\mathrm{C}^{14 \mathrm{O}_{2} \ddagger}\end{array}$ & Change \\
\hline 1 & 14 & Saline & 0 & $\begin{array}{c}\text { mumoles/100 mg protein } \\
16 \pm 4\end{array}$ & $\%$ \\
\hline 2 & 3 & Saline & + & $\begin{array}{c}28 \pm 3 \\
(p<0.001) \S\end{array}$ & +75 \\
\hline 3 & 14 & Ethanol & 0 & $\begin{array}{c}11 \pm 3 \\
(\mathrm{p}<0.001)\end{array}$ & -31 \\
\hline 4 & 4 & Ethanol & + & $\begin{array}{c}25 \pm 6 \\
(p<0.005)\end{array}$ & +62 \\
\hline
\end{tabular}

* Ethanol, $9.3 \mathrm{~g} / \mathrm{kg}$, as a $50 \%$ solution by volume or equivalent volumes of saline by stomach tube 16 hours before sacrifice.

$\dagger$ Nicotinamide, $500 \mathrm{mg} / \mathrm{kg}$, i.p. daily for 3 days prior to ethanol or saline administration.

$\ddagger$ Mean \pm SD.

$\S$ Compared with group 1 as control.

the hypophysectomized and cordotomized animals, ethanol failed to produce an increase in the total liver fat but under these conditions there was still a definite stimulation of $\mathrm{C}^{\mathbf{1 4}}$-acetate incorporation into lipid. It should be noted that these animals, because of their reduced ethanol tolerance, received a smaller dose $(6.2 \mathrm{~g}$ per $\mathrm{kg})$. This amount of ethanol, however, is quite effective in producing a fatty liver in normal rats (1).

\section{Palmitate-1-C $\mathrm{C}^{14}$ oxidation to $\mathrm{C}^{14} \mathrm{O}_{2}$}

In vitro studies. The addition of ethanol to homogenates of normal rat liver consistently produced a depression in the oxidation of $\mathrm{C}^{14}$-palmitate to $\mathrm{C}^{14} \mathrm{O}_{2}$. In Table III it will be noted that at a final ethanol concentration of $0.57 \mathrm{M}$ there was a mean inhibition of 48 per cent. Since it seemed possible that this effect might be secondary to increased levels of DPNH, as had been shown

TABLE V

Effect of DPN on C14-palmitate oxidation in liver homogenates of rats given saline or ethanol

\begin{tabular}{|c|c|c|c|c|}
\hline \multirow[b]{2}{*}{$\begin{array}{l}\text { No. of } \\
\text { animals }\end{array}$} & \multirow[b]{2}{*}{$\begin{array}{c}\text { Substance } \\
\text { administered* }\end{array}$} & \multicolumn{2}{|c|}{$\begin{array}{l}\mathrm{C}^{14} \text {-palmitate re- } \\
\text { covered as } \mathrm{C}^{14} \mathrm{O}_{2}\end{array}$} & \multirow[b]{2}{*}{$\begin{array}{l}\text { Change due to } \\
\text { DPN addition }\end{array}$} \\
\hline & & $\begin{array}{l}\text { Without } \\
\text { DPN }\end{array}$ & $\begin{array}{l}\text { With } \\
\text { DPN† }\end{array}$ & \\
\hline & & \multicolumn{2}{|c|}{$\underset{\text { protein }}{m \mu m o l e s ~} 100 \mathrm{mg}$} & $\%$ \\
\hline $\begin{array}{l}4 \\
4\end{array}$ & $\begin{array}{l}\text { Saline } \\
\text { Ethanol }\end{array}$ & $\begin{array}{l}17 \\
12\end{array}$ & $\begin{array}{l}46 \\
22\end{array}$ & $\begin{array}{r}+170 \\
+83\end{array}$ \\
\hline
\end{tabular}

* Ethanol, $9.3 \mathrm{~g} / \mathrm{kg}$, as a $50 \%$ solution by volume, or equivalent volume of saline by stomach tube 16 hours prior to sacrifice.

+ DPN, $2.75 \times 10^{-3} \mathrm{M}$, added to the incubation flask. to be the case for the impaired galactose oxidation produced by ethanol $(12,18)$, palmitate oxidation was measured in the presence of sorbitol and xylitol, substances which also serve to generate DPNH. Sorbitol and xylitol addition to the homogenates led to a similar although less pronounced inhibition as compared with ethanol (Table III). It should be noted, however, that the final concentration of these sugars in the homogenates was considerably below that of ethanol.

When palmitate oxidation was measured in liver homogenates of animals given ethanol (9.3 $\mathrm{g}$ per $\mathrm{kg}$ ) 16 hours previously, the oxidation was 31 per cent below that observed in homogenates from the livers of animals intubated with saline (Table IV). Evidence was obtained that this inhibition was not simply a nonspecific toxic effect of ethanol. Table IV shows that pretreatment of the rats with nicotinamide entirely reversed the inhibitory effect of ethanol on the oxidation of $\mathrm{C}^{14}$-palmitate to $\mathrm{C}^{14} \mathrm{O}_{2}$. In fact, in these homogenates, palmitate oxidation was 62 per cent greater than in those prepared from animals intubated with saline and not pretreated with nicotinamide.

Reversal of the inhibition of palmitate oxidation to $\mathrm{CO}_{2}$ was also readily obtained simply by increasing the DPN concentration in the homogenates. Table $\mathrm{V}$ shows that the addition of DPN $\left(2.75 \times 10^{-3} \mathrm{M}\right)$ to the incubation medium significantly increased the rate of palmitate oxidation in normal liver homogenates ( +170 per cent) 
as well as in homogenates of ethanol-treated animals ( +83 per cent).

In vivo studies. Experiments were carried out to measure the respiratory $\mathrm{C}^{14} \mathrm{O}_{2}$ production following the intraperitoneal injection of palmitate-1$\mathrm{C}^{14}$ in control animals (saline-treated) versus those receiving ethanol 16 hours previously. These results, shown in Figure 2, reveal a decrease in the labeling of the respiratory $\mathrm{CO}_{2}$ in the ethanol-treated animals compared with the saline controls. Similar results were obtained when the palmitate was injected 4 hours after ethanol or saline. It is of interest that when glucose was given in amounts isocaloric to ethanol, there was a depression in the liberation of respiratory $\mathrm{C}^{14} \mathrm{O}_{2}$ which was even greater than that observed in the ethanol-treated animals. However, this depres.sion of $\mathrm{C}^{14}$-palmitate oxidation by glucose, which has also been observed by Lossow and Chaikoff (19), does not result in an increase in total liver lipid.

\section{Alterations in hepatic levels of DPN and DPNH}

In Table II are recorded the changes in hepatic levels of DPN and DPNH following the administration of saline, ethanol, sorbitol, nicotinamide and nicotinamide plus ethanol. The effects of cordotomy, with and without subsequent ethanol treatment, are also recorded. As referred to above, ethanol at a dose of $9.3 \mathrm{~g}$ per $\mathrm{kg}$ produced almost a doubling of the DPNH levels in the liver without changing appreciably the total amount of DPN plus DPNH. As a result, the DPN/DPNH ratio in the liver tissue of these animals dropped from $6.32 \pm 1.90$ (saline controls) to $3.12 \pm 0.25$. Comparable results have been reported by Smith and Newman (20) in rats receiving smaller doses of ethanol ( $3 \mathrm{~g}$ per $\mathrm{kg}$ ). The administration of isocaloric amounts of sorbitol produced a similar but less striking drop in the DPN/DPNH ratio. Nicotinamide treatment produced not only a significant rise in DPN levels as described by Kaplan and co-workers (17) but also a pronounced increase in DPNH. As a result, the DPN/DPNH ratio was $5.65 \pm 0.82$. Of note was the fact that when the nicotinamide-injected rats were given ethanol, there was a still further increase in both $\mathrm{DPN}$ and DPNH resulting in a DPN/DPNH ratio of $5.01 \pm 2.33$. This nicotinamide pre-

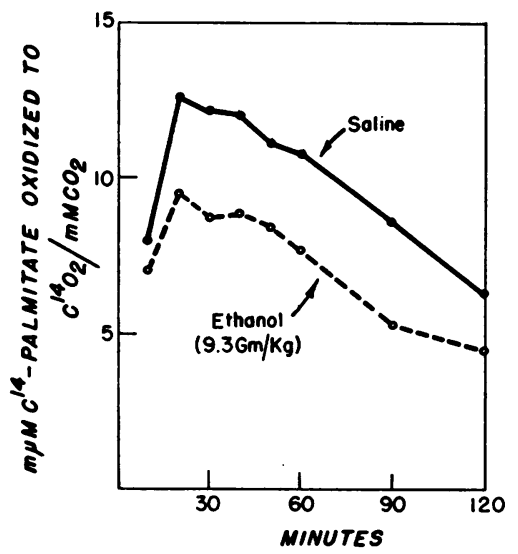

Fig. 2. EFFECT OF ETHANOL ADMINISTRation ON PALMitate-1-C ${ }^{14}$ oxidation to $\mathrm{C}^{14} \mathrm{O}_{2}$ IN VIVO. The animals were intubated with saline or ethanol 16 hours before receiving $250 \mathrm{~m} \mu$ moles of palmitate-1- $\mathrm{C}^{14}$ intraperitoneally. Respiratory $\mathrm{C}^{12} \mathrm{O}_{2}$ and $\mathrm{C}^{14} \mathrm{O}_{2}$ were measured as described under Methods. The points are mean values obtained from 4 animals in each group.

treatment prevented the marked drop in the DPN/DPNH ratio caused by ethanol alone.

The cordotomized rats were found to have somewhat higher levels of DPNH than the saline controls and as a result the mean DPN/ $\mathrm{DPNH}$ ratio was also lower $(4.52 \pm 0.63)$. However, when the cordotomized rats received ethanol, even though it was at a lower dose (6.2 $\mathrm{g}$ per $\mathrm{kg}$ ), there was still a significant drop in the DPN/DPNH ratio to $2.66 \pm 0.45$.

\section{DISCUSSION}

From the foregoing experiments and those reported by Lieber and co-workers $(4,5)$ it is evident that ethanol administration to rats stimulates the hepatic synthesis of fatty acids. This increased fatty acid synthesis, as reflected by the enhanced incorporation of $\mathrm{C}^{\mathbf{1 4}}$-acetate into lipid, appears to be related to the increased amounts of DPNH generated by the metabolism of ethanol in the liver. However, from the additional experiments with sorbitol and nicotinamide, it would appear that the incorporation of $\mathrm{C}^{14}$-acetate is more closely related to the DPN/DPNH ratio than to the actual levels of DPNH in the liver cells.

It should be emphasized that reduced triphosphopyridine nucleotide (TPNH) is perhaps more important and rate-limiting than is DPNH in the synthesis of fatty acids (21-23) by the liver. In 
fact, in the "malonate pathway" of fatty acid synthesis, believed by Green and Wakil (24) to be the major route for the de novo synthesis of long chain fatty acids, TPNH, not DPNH, is the required hydrogen donor. However, fatty acid synthesis also takes place in mitochondria by reversal of fatty acid oxidation and, in this scheme, DPNH is an essential cofactor $(25,26)$.

Although it might be postulated that the fatty liver induced by ethanol is primarily the result of increased hepatic fatty acid synthesis, our experiments do not support such a concept. It was noted that agents such as sorbitol or glucose, when given in amounts isocaloric to ethanol, were quite effective in stimulating $\mathrm{C}^{14}$-acetate incorporation into lipid but neither produced an increase in liver fat. In fact, in the glucose-treated animals the total liver lipid was actually decreased.

Of importance was the observation that pretreatment of rats with nicotinamide significantly diminished the incorporation of $\mathrm{C}^{14}$-acetate into lipid and yet the extent of the fatty liver was the same as in animals receiving ethanol alone (Figure 1). On the other hand, hypophysectomized and cordotomized animals failed to develop a fatty liver following ethanol administration, but the $\mathrm{C}^{14}$-acetate incorporation into lipid was still increased, especially in the cordotomized rats (Figure 1).

The dissociation of $\mathrm{C}^{14}$-acetate incorporation and the accumulation of fat in the liver demonstrated in these experiments, makes it unlikely that increased fatty acid synthesis by the liver is a major or important factor in the fatty liver induced by ethanol. It remains to be determined whether hepatic fatty acid synthesis is also unimportant in other forms of experimentally induced fatty liver.

Theoretically, an impairment in the utilization or oxidation of fatty acids by the liver might also be responsible for an increase in hepatic lipid. In this connection it was observed that the oxidation of palmitate-1-C ${ }^{14}$ to $\mathrm{C}^{14} \mathrm{O}_{2}$ in the whole animal was inhibited by ethanol administration. However, the administration of isocaloric amounts of glucose to rats produced a depression of palmitate oxidation in vivo which was even greater than that observed with ethanol; yet there was no increase in liver fat in the glucose-fed rats.
In studies on rat liver homogenates, the addition of ethanol to the incubation system caused a decrease in the production of $\mathrm{C}^{14} \mathrm{O}_{2}$ from $\mathrm{C}^{14}$ palmitate which seemed related, at least in part, to changes in the state of the oxidized and reduced pyridine nucleotides produced by ethanol. Thus, addition to the homogenates of two other substances which generate DPNH (i.e., sorbitol and xylitol), also caused a depression in $\mathrm{C}^{14} \mathrm{O}_{2}$ formation. On the other hand, addition of DPN to the incubation system, or the use of liver homogenates from nicotinamide-injected rats, completely prevented the inhibitory effect of ethanol on $\mathrm{C}^{14}$-palmitate oxidation to $\mathrm{C}^{14} \mathrm{O}_{2}$. Lieber and Schmid (5) have also observed an inhibition by ethanol of palmitate-1-C ${ }^{14}$ oxidation to $\mathrm{C}^{14} \mathrm{O}_{2}$ in liver slices. They have suggested that this inhibition may be due to a decrease in the oxidation of tricarboxylic acid cycle intermediates by DPNH.

It should be emphasized that any interpretations of the changes in the conversion of palmitate-1-C ${ }^{14}$ to $\mathrm{C}^{14} \mathrm{O}_{2}$ in vivo and in vitro are complicated by possible alterations in pool size. In the in vivo experiments the mobilization of free fatty acids from adipose tissue by ethanol $(6,27)$ will tend to dilute the $\mathrm{C}^{14}$-palmitate pool. At the same time the effects of fasting will tend to increase palmitate oxidation (28). The acetyl coenzyme A pool from which the $\mathrm{C}^{14} \mathrm{O}_{2}$ is derived will also tend to be diluted by the oxidative metabolism of ethanol to acetate and acetyl coenzyme A. Nevertheless, it is evident from the experiments with nicotinamide that the effect of ethanol on palmitate oxidation can be dissociated from the fatty liver induced by ethanol.

The experiments presented above do not provide the definitive answer as to the mechanism involved in the development of the ethanol-induced fatty liver. They serve to emphasize, however, that increased hepatic fatty acid synthesis and impaired fatty acid oxidation by the liver are not major or primary factors in this process. The inference is drawn that derangements in lipid transport are probably the significant factors in the pathogenesis of the fatty liver. In a recent preliminary report Maling and associates (6) suggest that ethanol and agents such as ethionine and carbon tetrachloride induce a fatty liver by in- 
creasing fat mobilization from peripheral adipose tissues. However, Recknagel, Lombardi and Schotz (29), on the basis of experiments with carbon tetrachloride, favor the concept that the fatty liver results primarily from a decrease in the release of lipid from the liver. In view of these conflicting theories, further experiments are in progress in this laboratory to evaluate the role of alterations in lipid transport in the pathogenesis of the fatty liver produced by ethanol.

\section{SUM MARY}

1. In order to elucidate the mechanism involved in the fatty liver induced by ethanol intoxication in rats, studies have been carried out on the effects of ethanol on the incorporation of acetate-1- $\mathrm{C}^{14}$ into lipid and the oxidation of palmitate-1- $\mathrm{C}^{14}$ to $\mathrm{C}^{14} \mathrm{O}_{2}$ in liver.

2. Ethanol administration to rats stimulated the incorporation of acetate-1- $\mathrm{C}^{14}$ into liver lipids. However, glucose and sorbitol stimulated $\mathrm{C}^{\mathbf{1 4}}$ acetate incorporation into lipid without producing an increase in liver fat.

3. Injection of animals with nicotinamide prior to ethanol treatment depressed the incorporation of $\mathrm{C}^{14}$-acetate into lipid, but the extent of the fatty liver was unaltered. Conversely, hypophysectomy and cordotomy prevented the fatty liver, but $\mathrm{C}^{14}$-acetate incorporation remained increased.

4. Ethanol produced almost a doubling in the amount of reduced diphosphopyridine nucleotide $(\mathrm{DPNH})$ in the liver and a decrease in the $\mathrm{DPN} / \mathrm{DPNH}$ ratio. However, increasing the DPNH levels or decreasing the DPN/DPNH ratio by other means, such as by sorbitol administration, did not result in a fatty liver.

5. Palmitate-1-C $\mathrm{C}^{14}$ oxidation to $\mathrm{C}^{14} \mathrm{O}_{2}$ was depressed by ethanol, both in vivo and in vitro. Prior treatment of the animals with nicotinamide completely prevented this inhibitory effect of ethanol but the extent of the fatty liver was unchanged.

6. It is concluded that the fatty liver following acute ethanol intoxication in rats is not directly related to an increased synthesis or a decreased oxidation of fatty acids in the liver. Derangements in lipid transport are probably the important factors in the production of the ethanol-induced fatty liver.

\section{ACKNOWLEDGMENTS}

The authors are indebted to Mrs. G. Winter and Miss D. Budz for their valuable technical assistance.

\section{REFERENCES}

1. Mallov, S., and Bloch, J. L. Role of hypophysis and adrenals in fatty infiltration of liver resulting from acute ethanol intoxication. Amer. J. Physiol. 1956, 184, 29.

2. Di Luzio, N. R. Effect of acute ethanol intoxication on liver and plasma lipid fractions of the rat. Amer. J. Physiol. 1958, 194, 453.

3. Mallov, S. Effect of adrenalectomy on ethanol and fat metabolism in the rat. Amer. J. Physiol. 1957, 189, 428.

4. Lieber, C. S., DeCarli, L. M., and Schmid, R. Effect of ethanol on fatty acid metabolism in liver slices. Biochem. biophys. Res. Com. 1959, 1, 302.

5. Lieber, C. S., and Schmid, R. The effect of ethanol on fatty acid metabolism; stimulation of hepatic fatty acid synthesis in vitro. J. clin. Invest. 1961, 40, 394.

6. Maling, H. M., Horning, M. G., Butler, W. M., Jr., Highman, B., and Brodie, B. B. Triglyceride deposition in rat liver through derangement of fat transport by various chemical agents. Fed. Proc. 1960, 19, 229.

7. Calvert, D. N., and Brody, T. M. Role of the sympathetic nervous system in $\mathrm{CCl}_{\mathbf{t}}$ hepatotoxicity. Amer. J. Physiol. 1960, 198, 669.

8. Dawson, A. M., and Isselbacher, K. J. The esterification of palmitate-1-C $\mathrm{C}^{\mathbf{1 4}}$ by homogenates of intestinal mucosa. J. clin. Invest. 1960, 39, 150.

9. Eisenberg, F., Jr. Round-table on: Preparation of the alkaline absorbent for radioactive $\mathrm{CO}_{2}$ in liquid scintillation counting in Liquid Scintillation Counting, C. G. Bell, Jr. and N. F. Hayes, Eds. New York, Pergamon Press, 1958, p. 123.

10. Folch, J., Lees, M., and Sloane Stanley, G. H. A simple method for the isolation and purification of total lipides from animal tissues. J. biol. Chem. 1957, 226, 497.

11. Albrink, M. J. The microtitration of total fatty acids of serum, with notes on the estimation of triglycerides. J. Lip. Res. 1959, 1, 53.

12. Isselbacher, K. J., and McCarthy, E. A. The influence of pyridine nucleotides on galactose-1- $\mathrm{C}^{\mathbf{1 4}}$ oxidation to $\mathrm{C}^{14} \mathrm{O}_{2}$ in vitro. Biochem. biophys. Res. Com. 1959, 1, 49.

13. Fredrickscn, D. S., and Ono, K. An improved technique for assay of $\mathrm{C}^{14} \mathrm{O}_{2}$ in expired air using the liquid scintillation counter. J. Lab. clin. Med. 1958, $51,147$.

14. Ciotti, M. M., and Kaplan, N. O. Procedures for determination of pyridine nucleotides in Methods in Enzymology, S. P. Colowick and N. O. Kaplan, 
Eds. New York, Academic Press, 1957, vol. 3, p. 890 .

15. Layne, E. Spectrophotometric and turbidometric methods for measuring proteins in Methods in Enzymology, S. P. Colowick and N. O. Kaplan, Eds. New York, Academic Press, 1957, vol. 3, p. 447.

16. Isselbacher, K. J., and Krane, S. M. Mechanism of the inhibition of galactose-1-C $\mathrm{C}^{14}$ oxidation to $\mathrm{C}^{14} \mathrm{O}_{2}$ by ethanol. J. biol. Chem. In press.

17. Kaplan, N. O., Goldin, A., Humphreys, S. R., Ciotti, M. M., and Stolzenbach, F. E. Pyridine nucleotide synthesis in the mouse. J. biol. Chem. 1956, 219, 287.

18. Isselbacher, K. J., and McCarthy, E. A. Effects of alcohol on the liver: Mechanism of the impaired galactose utilization. J. clin. Invest. 1960, 39, 999.

19. Lossow, W. J., and Chaikoff, I. L. Carbohydrate sparing of fatty acid oxidation. I. The relation of fatty acid chain length to the degree of sparing. II. The mechanism by which carbohydrate spares the oxidation of palmitic acid. Arch. Biochem. 1955, 57, 23.

20. Smith, M. E., and Newman, H. W. The rate of ethanol metabolism in fed and fasting animals. J. biol. Chem. 1959, 234, 1544.

21. Langdon, R. G. The requirement of triphosphopyridine nucleotide in fatty acid synthesis. J. Amer. chem. Soc. $1955,77,5190$.
22. Siperstein, M. D., and Fagan, V. M. Studies on the relationship between glucose oxidation and intermediary metabolism. I. The influence of glycolysis on the synthesis of cholesterol and fatty acid in normal liver. J. clin. Invest. 1958, 37, 1185.

23. Wakil, S. J., and Ganguly, J. On the mechanism of fatty acid synthesis. J. Amer. chem. Soc. 1959, 81, 2597.

24. Green, D. E., and Wakil, S. J. Enzymatic mechanisms of fatty acid oxidation and synthesis in Lipide Metabolism, K. Bloch, Ed. New York, John Wiley and Sons, 1960, p. 1.

25. Seubert, W., Greull, G., and Lynen, F. The synthesis of fatty acids by means of purified enzymes of the aliphatic series. Angew. Chem. 1957, 69, 359.

26. Wakil, S. J., McLain, L. W., Jr., and Warshaw, J. B. Synthesis of fatty acids by mitochondria (prelim. communic.) J. biol. Chem. 1960, 235, 31.

27. Rebouças, G., and Isselbacher, K. J. Unpublished observations.

28. Geyer, R. P., Bowie, E. J., and Bates, J. C. Effects of fasting and pyruvate on palmitic acid metabolism. J. biol. Chem. 1953, 200, 271.

29. Recknagel, R. O., Lombardi, B., and Schotz, M. C. A new insight into pathogenesis of carbon tetrachloride fat infiltration. Proc. Soc. exp. Biol. (N. Y.) $1960,104,608$.

\section{SPECIAL NOTICE TO SUBSCRIBERS}

Post Offices will no longer forward the Journal when you move.

Please notify The Journal of Clinical Investigation, Business

Office, 333 Cedar Street, New Haven 11, Conn., at once when you have a change of address, and do not omit the zone number if there is one. 